\title{
Effects of Information and Communication Technologies on the Banking Inclusion of Populations in the West African Economic and Monetary Union
}

\author{
Moussa Coulibaly \\ Department of Economics and Management, Ouaga II University, Ouagadougou, Burkina Faso \\ Email address: \\ mousscoulb@gmail.com

\section{To cite this article:} \\ Moussa Coulibaly. Effects of Information and Communication Technologies on the Banking Inclusion of Populations in the West African \\ Economic and Monetary Union. International Journal of Finance and Banking Research. Vol. 6, No. 4, 2020, pp. 74-82. \\ doi: $10.11648 /$ j.ijfbr.20200604.13
}

Received: July 2, 2020; Accepted: August 6, 2020; Published: August 13, 2020

\begin{abstract}
This article analyzes the effects of information and communication technologies on the level of banking inclusion of populations in the West African Economic and Monetary Union (WAEMU). To this end, it is a contribution to the exploration of new and innovative ways of solving the problem of banking exclusion of populations in an area where more than half of the adult population remains excluded from the financial system in general. The theoretical frameworks used in this research are those of the frontier theory of access possibilities and access barriers to financial services, and client selection theory. A linear model based on panel data has been adopted in this article to analyze the empirical link between information and communication technologies and the banking inclusion index of the populations in the Union over the period 2006-2016. The model was estimated using the panel-corrected standard error method. The results show that the use of ATMs and the Internet diffusion among the WAEMU population positively and significantly influence the level of banking inclusion of the WAEMU population. The use of information and communication technologies by both the population and the banks is an innovative way of improving the level of banking inclusion of the Union population. To improve banking inclusion in the Union, the article encourages banks and the population to rely more on the use of these technologies.
\end{abstract}

Keywords: Banks, ICT, Banking Inclusion of Populations, WAEMU

\section{Introduction}

In the West African Economic and Monetary Union (WAEMU ${ }^{1}$ ), financial development policies have always accompanied the financial system [1], with a view to enabling it to play its full role in the economies of the Union. However, despite these policies, the financial sector in WAEMU remains less inclusive. It is essentially limited to the banking sector ${ }^{2}$. Moreover, in the Union in $2017,83 \%$ of the adult population remained unbanked in the strict sense of the banking rate [2]. In a broad sense, $64.10 \%$ of the adult population remained excluded from the financial system in

1 The WAEMU includes eight West African countries, which are: Benin, Burkina Faso, Cote D'Ivoire, Guinea-Bissau, Mali, Niger, Senegal and Togo.

$299.71 \%$ of all credit in the Union's financial system in 2015 was provided by banks. This value was calculated by the author on the basis of statistics from the Central Bank of West African States (CBWAS), 2019. the WAEMU in 2017, according to the same source. This observation on the banking sector, particularly in the Union, shows that the situation regarding the banking inclusion of the population remains problematic.

In the literature, this strong banking exclusion in the Union can be explained at various levels. Imperfections in the banking market, which are rooted in information asymmetries [3, 4] and poor quality of institutions [5, 6], are generally put forward as causes. A reduction in these banking market imperfections therefore contributes favourably to reducing the level of banking exclusion of populations in the WAEMU.

Irrespective of these sources of banking exclusion of populations, the customer selection theory explains that some individuals may be excluded from banking services because of certain characteristics that are particular to them [7]. These include their remoteness from banking service points. In the 
WAEMU in $2017,25 \%$ of adults without an account with a financial institution cited distance as the cause [8]. Innovative use of information and communication technologies (ICTs) by both banks and the population in the exercise of the bankclient relationship is likely to counter this problem of exclusion of the population from the banking system due to distance. ICTs are a real means of reducing time and space in the exercise of the banking profession $[9,10]$. They offer banks the possibility of interacting with their customers more and more rapidly over time and further and further away in space in the exercise of their banking activities.

Part of the population may also be excluded from banking services because of insufficient supply of banking services on the banking side or insufficient demand for banking services on the population side [11]. This lack of supply of or demand for banking services depends in part on the production technology used by banks to provide banking services to people or the technology used by people to access banking services [11]. ICTs can also be used by banks as a standalone factor or incorporated into conventional factors of production (labor and capital) to improve the level of supply of banking services to populations. In this sense, the use of ICTs by banks is likely to have an impact on the banking exclusion of the population, which is due to the insufficient supply of banking services to the population.

From a theoretical point of view, it appears that the use of ICTs both by banks in the exercise of their business and by the population in their relations with banks can contribute to improving the level of banking inclusion of the population. In order to compare this theoretical view with empirical evidence in the WAEMU, this research asks the question: What are the effects of ICTs on the banking inclusion of populations in the WAEMU? The objective of the research is to analyze the effects of ICTs on the banking inclusion of populations in the Union. This research aims to contribute to the exploration of new solutions to improve the level of banking inclusion of populations in particular in the WAEMU and in developing countries in general. This research is based on the premise that ICTs significantly improve the level of banking inclusion of populations in the WAEMU.

The continuation of the research presents in a second section some stylized facts on the theme. A third section presents the literature review. The fourth and the fifth sections present respectively the analysis method and the results and discussions of the research. The last section is devoted to the conclusion and implications of the research.

\section{Stylized Facts on the Use of ICTs for Banking Inclusion in WAEMU}

ICTs have given rise to new financial institutions such as Fin Tech and mobile money establishments. In the WAEMU in particular, they are increasingly solicited by mobile phone operators to offer innovative financial services to populations. The following figure illustrates the evolution of mobile money in the Union over the period 2013-2016.

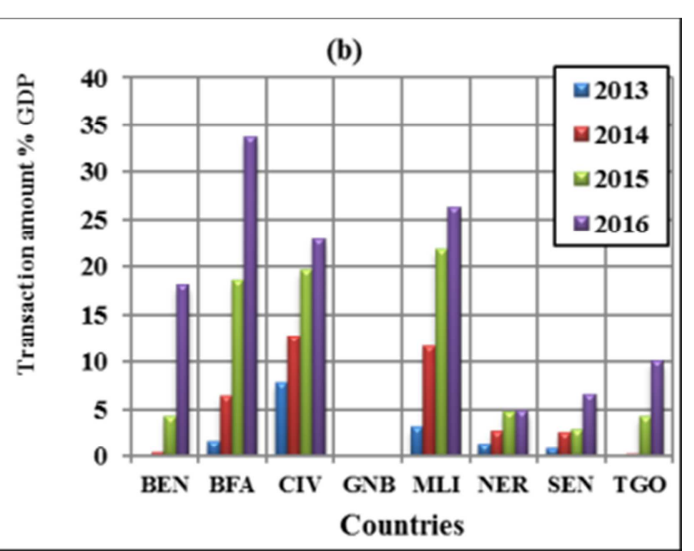

Figure 1. Situation of mobile money by country in the WAEMU.

Note: $\mathrm{BEN}=$ Benin, $\mathrm{BFA}=$ Burkina Faso, $\mathrm{CIV}=$ Cote D'Ivoire, $\mathrm{GNB}=$ Guinea-Bissau, $\mathrm{MLI}=\mathrm{Mali}$, NER=Niger, $\mathrm{SEN}=\mathrm{Senegal}$, TGO=Togo.

Source: Author using data from Word Economic Outlook [WEO], 2018.

Figure 1-(a) shows that the number of active mobile money accounts per 1,000 inhabitants will increase steadily from 2013 to 2016 in most WAEMU countries. Figure 1-(b) shows that, during the four reference years, the volume of transactions as a percentage of GDP through mobile money is also increasing steadily in all WAEMU countries. Burkina Faso, Côte d'Ivoire and Mali remain, during this period, the countries where this technology was most used for monetary transactions. The advent of mobile money in the WAEMU contributed $19.5 \%$ to the improvement in the overall rate of use of financial services in 2017 [2].

For the population, the sustainability and strengthening of mobile money is therefore to be hoped for. However, mobile money can be considered a threat by traditional banks. In fact, the largest telephone operator (Orange), which provided mobile money services in cooperation with banks in the WAEMU, set itself up in 2019 as an "electronic money institution". It will therefore compete directly with traditional banks in offering payment services to the population.

In order to face competition from these new players in the 
financial sector in general, traditional banks are forced to digitize banking services to the population. At present in the Union, they are improving the level of their automated public banking services by installing and operating automatic teller machines (ATMs). They are also engaged in offering mobile banking services to the public through mobile banking. These banking technologies are gradually spreading within the Union banking sector. The following figure shows the level of ATM penetration in the Union over the period 2010-2016.

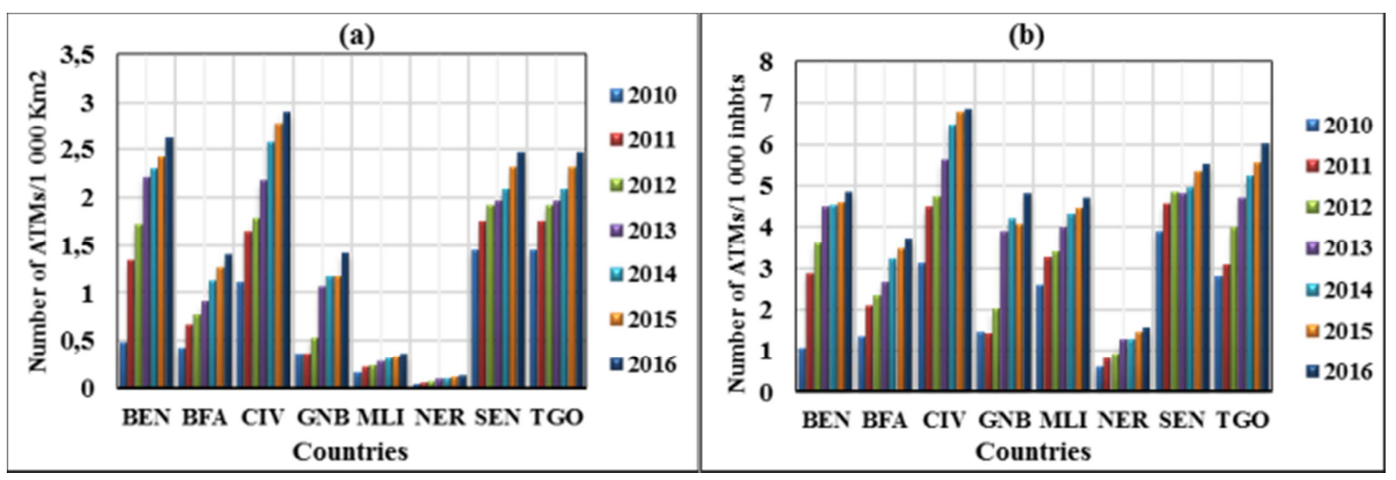

Source: Author based on BCEAO data, 2018.

Figure 2. Situation of ATMs by country in WAEMU.

Over the period under review, the number of ATMs per 1 $000 \mathrm{~km} 2$ (Figure 2-(a)) and the number of ATMs per 1000 inhabitants (Figure 2-(b)) have been steadily increasing in all Union countries. Populations are making greater use of them to access banking services. The percentage of respondents having an account with a bank or other financial institution and generally reporting that they obtain cash from their account at an ATM increased in 2014 (19.32\%) compared to $2011(5.15 \%)$ in the Union [8]. The use of this technology by banks can be a means of improving their accessibility to the public.

Mobile banking is also a reality in the WAEMU. Its advent is recent in the Union. Unlike ATMs, mobile banking allows banks to offer online banking services to people wherever they are, provided they have access to the Internet. People can access these online services through a mobile banking application, which can be downloaded online from the Google Play Store or the App Store and installed on a computer, tablet or mobile phone. Banks are thus able to send their service offerings to certain populations that are far from banking service points. The major constraint to the use of this banking technology remains, however, the low diffusion of the Internet in the WAEMU. According to International Telecommunication Union (ITU) statistics of 2018, only 18 out of 100 people at most used the Internet in the Union in 2017.

The stylized facts show that people use ICTs to access banking services in the Union. It also shows that banks are using ICTs to provide banking services to the population. The next step in this research is to see whether this use of ICTs by both banks and populations in the exercise of the bank-client relationship is likely to have a positive impact on the banking inclusion capacity of populations in the WAEMU.

\section{Literature Review}

At the theoretical level, the research is based on the frontier theory of access possibilities and access barriers to financial services [11] and on the customer selection theory [7]. These two theories link ICTs and the financial inclusion of populations in general and banks in particular.

On the supply side, part of the population may be excluded from the financial system because of a shortage of financial services, which is itself a result of the borderline limitation on access [11]. A set of explanatory factors behind the access frontier can be mobilized. On the one hand, there are factors that are the responsibility of the financial system itself, such as the production technology it uses, the quality of management and investment decisions of financial institutions, and the production costs of financial institutions (fixed costs of facilities and transaction costs of financial services). On the other hand, there are state variables such as systemic risk in general, financial regulation and macroeconomic fundamentals.

On the demand side of the financial services market, part of the population may also be excluded from the financial system either voluntarily or involuntarily through a limitation or borderline of access. This demand frontier may result from economic or non-economic factors, which can be grouped into variables specific to the individual who is excluded and state variables. In terms of variables specific to the individual, there is the price of financial services, the level of his or her income, literacy level, culture, religion. In terms of state variables, there is the size of the financial market, other macroeconomic fundamentals, the distribution of per capita income, available technology, the environment and physical infrastructure (especially financial).

In the face of financial exclusion due to the existence of a frontier of access opportunities, both on the supply and demand side, the solution is to push the frontier. One of the ways of pushing back a frontier of production possibilities is the adoption and use of a new technology. For example, the intensive use of ICTs in the financial sector is likely to push the frontier of access to financial services. Therefore, ICTs 
are likely to improve the level of inclusiveness of the financial system.

In terms of barrier theory, it explains financial exclusion not because there is an insufficient supply of financial services or a low demand for financial services, but rather because there are a number of barriers that prevent people from accessing financial services. These are mainly financial, physical and eligibility barriers. The financial and eligibility barriers include the conditions for opening and managing deposit accounts as well as all the documents to be provided when opening such accounts. The physical barrier refers to the distance a customer must travel to access a financial counter. It is also mention it as a source of financial exclusion of populations [7].

The use of ICTs by populations and the financial system helps to partially overcome access barriers, especially physical ones. Indeed, ICTs are a real means of reducing time and space $[9,10]$. For example, ICTs enable the financial system to reduce the distance that customers have to travel by offering mobile, online and ATM-based financial services. This is likely to improve access to financial services for the population and therefore improve the inclusiveness of the financial system in general.

In the empirical literature, several factors are cited as determinants of the level of financial inclusion of populations These include economic factors (per capita income of populations), non-economic factors (financial education of populations, cultural and religious barriers, quality of information) and institutional factors outside the financial system (quality of institutions). This research recognizes the importance of all these factors in explaining the level of financial inclusion of populations. It chooses to dispense with empirical analyses that have focused on these determinants to focus on the analysis of the effects of ICTs on people's level of financial inclusion.

Thus, this research refers to a few authors who have already analyzed the link between ICTs and the banking inclusion of populations. However, it should be noted that there is much more discussion in the empirical literature about the link between ICTs and financial inclusion in general. Nevertheless, it should also be noted that the banking system is generally the gateway to other forms of financial services [12]. To this end, "banking inclusion or exclusion" is often used by analogy to "financial inclusion or exclusion", according to the author. This analogy can be used to assimilate the findings of research that has used either of these two ICT-related concepts. This research restricts the analysis only to the level of banks for the reason that, currently in the Union, among financial institutions, only banks offer services to the population in an automated or online way through ATMs and mobile banking respectively.

Among the empirical studies to which this research refers, there is that of [13]. These authors used a sample of African countries to assess the effects of mobile phone penetration on financial inclusion. Their period of analysis runs from 2000 to 2007 . Their results show that mobile phone development is strongly and positively correlated with financial inclusion.
[14] found a positive and significant effect of ATMs on the level of financial inclusion in a sample of 31 UNCTAD countries.

[15] carried out an empirical analysis of the role of ICT infrastructure on financial inclusion in India over the period 1995-2013. Their results indicate that ICT infrastructure such as telephone lines, mobile phones and internet use are positively associated with the level of financial inclusion. These findings lead the authors to argue that connectivity and information play an important role in financial inclusion in India. [16] analyzed the impact of mobile banking on financial inclusion in Zimbabwe. The authors adopted a qualitative research methodology that involved a survey in Masvingo province in Zimbabwe. Their findings reveal that low-income people are more likely to adopt mobile banking because it is easily accessible, convenient, cheaper, secure and easy to use. Given that it is low-income people who are most excluded from the financial system, their research findings also show that ICTs are an important means of financial inclusion in Zimbabwe. [17] argues through a number of tests that ICTs are a tool that urban populations use to access financial services in India. In Nigeria, [18] find that people's use of the Internet is a determinant of financial inclusion over the period 1990-2016.

Thus, all the above empirical research seems to be unanimous on the ability of ICTs to improve the level of inclusion of a banking system that uses them. Nevertheless, they view financial inclusion as a one-dimensional phenomenon, which is rather debatable according to some authors [19, 20]. While adopting a multidimensional approach to the phenomenon of banking inclusion, the empirical component of this research will highlight the empirical link between the use of ICTs in the WAEMU and the degree of inclusion of populations in its banking system.

\section{Method of Analysis}

\subsection{Econometric Model}

Referring to the work of $[21,15,22]$, the research adopts a linear model to analyze the effects of ICTs on the level of banking inclusion of populations in the WAEMU. The econometric model readapted by [21] to analyze the relationship between ICTs and the banking inclusion of populations is as follows:

$$
I F I_{i t}=X_{i t} \beta+Z_{i t} \gamma+\varepsilon_{i t}
$$

In this model, IFI denotes the banking inclusion index of the populations, $X$ is the vector of variables of interest representing ICT, $Z$ represents the vector of control variables and the $\varepsilon$ error term. $i$ and $t$ represent the individual and time dimensions of the model, respectively.

\subsubsection{Definition of the Dependent Variable of the Model}

The model's dependent variable is the banking inclusion of populations (IFI). The research uses a composite index to measure the level of banking inclusion of populations in the Union as the dependent variable. It is calculated in 
accordance with Sarma's methodology [12]. According to this author, a financial system is inclusive only when financial services are available and accessible to the populations and when these same populations actually use financial services. The author combines three dimensions of banking inclusion of populations in the calculation of the composite index. The first dimension relates to the "penetration or accessibility" dimension of banking services to populations. The number of bank deposit accounts per 1,000 adult persons is used as an indicator of this dimension. The second dimension relates to the dimension of availability of banking services to the population. The number of bank branches per 100,000 adults is used as an indicator for this dimension. The third dimension relates to the dimension of actual use of banking services by the population. The volumes of credit to the private sector and private sector deposits as a proportion of GDP is used as an indicator of this dimension.

\subsubsection{Definition of the Independent Variables of the Model}

The independent variables of the model are the variables of interest and the control variables. The variables representing ICT are the variables of interest in the model. Two variables of interest are used in this research. They come from previous work $[23,21,15,24]$. These are the number of ATMs per 1,000 km2 (denoted ATM in the model) and the number of Internet users per 100 inhabitants (denoted INT in the model). The variables of interest, as a whole, are assumed to positively influence the level of banking inclusion of the populations in the Union.

The control variables are a set of variables, apart from the variables of interest, that are likely to influence the level of inclusion of a financial system. They include variables of different kinds. They are chosen in this research according to their relevance in explaining the level of banking inclusion of populations and also according to the availability of data.

This research includes in this list of variables, a demographic variable captured by population density (PD). The most densely populated areas are more likely to be served by banks because they have a better chance of profitability for banks [25]. Since banking presence is a source of banking inclusion of populations, a positive relationship between population density and the level of banking inclusion of populations can be inferred by ricochet. This variable was used by $[21,26]$ in their explanation of the level of financial inclusion.

The control variables also include a macroeconomic variable captured by the level of GDP per capita. It is used to analyze the effect of economic development on the banking inclusion of populations. This variable was also used by [21]. A positive sign is expected between it and the level of banking inclusion of populations. An institutional variable is likewise taken into account in the control variables. This is the quality of institutions (noted INST in the model). It is captured by the inverse of the index obtained from the average of the political law index and the civil liberties index. It is assumed to have a positive effect on the level of banking inclusion of populations in accordance with North's neoinstitutional theory, which positively relates the quality of institutions to economic performance in general.

Two final variables to be included in the list of control variables concern the banks' cost of operations (COE) and the average weighted average bank lending rates (WAR) applied to loans to individuals and to those of private non-financial firms. Bank operating costs are measured by the ratio of banks' general expenses to their total balance sheet. Bank operating costs are expected to have a negative impact on the level of banking inclusion of the population because they are a constraint on the production of banking services to the population. The sign between the banks' lending interest rate and the level of banking inclusion of the population is undetermined. A fall in the lending interest rate stimulates the demand for banking services while a rise is likely to stimulate the supply of banking services. On both sides, this action is likely to have a positive effect on the level of banking inclusion of the population.

The final model to be estimated is written as follows, taking into account all the above-mentioned variables (interest and control variables):

$$
I F I_{i t}=\beta_{0}+\beta_{1} G A B_{i t}+\beta_{2} I N T_{i t}+\beta_{3} G D P_{i t}+\beta_{4} I N S T_{i t}+\beta_{5} C O E_{i t}+\beta_{6} W A R_{i t}+\beta_{7} P D_{i t}+\varepsilon_{i t}
$$

\subsection{Presentation of Analysis Data}

The data on the Internet come from the International Telecommunication Union database. For the rest of the variables in model (2), the data come from the statistics of the BCEAO, the World Bank and Freedom House. The analysis period is from 2006 to 2016. This choice is guided by the availability of data, particularly those relating to the number of bank accounts. The panel selected is a noncylinder panel due to the fact that ATMs data are not available before 2010 .

\subsection{Presentation of the Model Estimation Method}

Preliminary tests were conducted on the sample data. These tests are mainly the stationarity test of the variables and the autocorrelation test between the variables of the model. The results of these tests showed that some of the model variables are level stationary (bank inclusion index of populations, bank operating costs and ATMs density) while the others are first difference stationary. The order of stationarity of the variables is taken into account to avoid the risk of spurious regression. The results of the autocorrelation tests showed that some of the explanatory variables in the model are correlated with each other. Their simultaneous use in model estimation could lead to biased estimators, if the estimator used is not able to account for this autocorrelation.

In this research, the sample size used is small and also has the peculiarity that the individual dimension of the data is not worth at least twice their time dimension. 
Given these characteristics of the sample and the fact that certain explanatory variables are correlated with each other, this research uses the Panel Corrected Standard Errors (PCSE) estimator. The PCSE is one of the most appropriate estimators for estimating the model with such data [27].

\section{Results and Interpretations}

\subsection{Descriptive Data Analysis}

After calculation by the author, the values of the banking inclusion index over the period 2006-2016 for all WAEMU countries are presented in the following figure 3 :

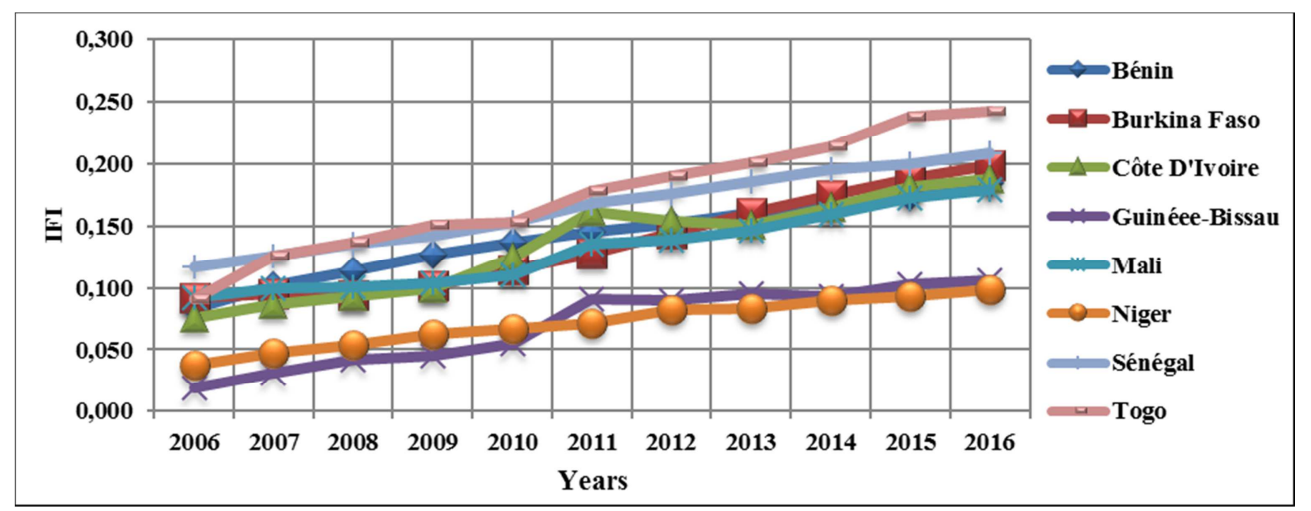

Source: Author after calculation of the IFI from BCEAO data, 2018.

Figure 3. Evolution of the banking inclusion index of populations in WAEMU.

This index evolves on a scale of 0 to 1 . The minimum value of " 0 " is synonymous with total exclusion from banking for the population and the maximum value of "1" is synonymous with a banking system that is totally inclusive for the population. Over the 2006-2016 period, the level of banking inclusion of the populations in WAEMU countries remained low in comparison with the index values, which are closer to "0" than to "1". However, it can be seen from the figure that the level of banking inclusion of the populations in each of the countries of the Union is improving, even if the pace of improvement is slow.

The descriptive statistics of the model's variables are presented in Table 1. They are deliberately reduced for the three variables of interest.

Table 1. Descriptive statistics of the data for the variables of interest in the sample.

\begin{tabular}{lllll}
\hline Variables & Average & Standard Error & Minimum & Maximum \\
\hline IFI & 0,128 & 0,0494 & 0,019 & 0,242 \\
Internet & 5,456 & 5,733 & 0,294 & 26,527 \\
ATMs density & 1,476 & 1,211 & 0,038 & 4,684 \\
\hline
\end{tabular}

Source: Author's estimate.

These statistics show that the average level of the banking inclusion index of the populations in the Union is 0.128 . Consequently, it is low overall over the period 2006-2016. The maximum value of this index in the Union over the analysis period is 0.387 . In the Union, on average, 5 out of every 100 people surveyed over the period 2006-2016 use the Internet. Over the same analysis period, the number of internet users per 100 persons hardly exceeded 27 . It should be recalled that the internet is the medium used by mobile banking. Thus, this state of affairs regarding the spread of the Internet in the Union is not such as to support the spread of the use of mobile banking among the general public. In the WAEMU, there will be on average about 1 ATM in every $1,000 \mathrm{~km}^{2}$ of space over the $2010-2016$ period. At most, there can only be a maximum of 4 ATMs for every $1,000 \mathrm{~km}^{2}$ in the Union.

\subsection{Results of the Estimation of the Model}

The following table presents the results of the estimation of the research model.
Table 2. Estimation results of the research model.

\begin{tabular}{lll}
\hline PCSE estimator & & \\
\hline Banking inclusion of populations & Coefficients & Z-statistics \\
\hline AMTs density & $0.0132^{* * *}$ & 2.94 \\
Internet & $0.0019^{* *}$ & 2.27 \\
GDP per capita & $0.0128^{* * *}$ & 6.88 \\
Institution quality & -0.0046 & -0.11 \\
Bank operating costs & $-1.072^{*}$ & -1.91 \\
Bank lending rates & $0.0074 * *$ & 2.23 \\
Population density & 0.0018 & 1.24 \\
Rho statistic & 0.6815 & \\
Wald test & Prob $>$ Chi2 $=0.0000$ & \\
Adjusted $\mathrm{R}^{2}$ & 0.9346 & \\
\hline
\end{tabular}

$* * *, * *$ and $*$ denote the significance of the coefficients at $1 \%, 5 \%$ and $10 \%$ respectively.

Source: Author's estimate based on data from the analysis.

In Table 2, the values of the adjusted ${ }^{3} \mathrm{R}^{2}$ and Wald statistic

3 Calculated by the author based on the following formula Adjusted $R^{2}=1-$ $\left(1-R^{2}\right) \frac{n-1}{n-K-1}$, where $\mathrm{n}=$ number of observations and $\mathrm{K}=$ number of explanatory variables in the model. 
show that the model is generally well-fitted. The relatively high Rho value shows that the incorporation of the autocorrelation correction in the model is not negligible. It therefore appears that the results are statistically valid and can be interpreted. The coefficients associated with the explanatory variables respectively represent the marginal effect of each of them on the level of banking inclusion of the populations in the Union.

The results show that the number of ATMs per 1,000 km2 positively and significantly influences the level of banking inclusion of the populations in the WAEMU over the analysis period. These results also show that the relationship between the number of Internet users and the level of banking inclusion of the populations is positive and significant in the Union.

The significant and positive relationship between the spatial distribution of ATMs and the level of banking inclusion of the populations in the WAEMU over the analysis period indicates that an increase in the number of ATMs followed by a better geographical distribution of these ATMs improves the level of banking inclusion of the populations in the Union. ATMs allow banks to expand their banking network to be physically more accessible to populations in locations where the presence of a bank branch might not be considered profitable for a bank. Stylized facts show that people are increasingly using ATMs for their banking transactions. Thus, banks can use them to effectively improve their level of banking services to the population. This result between the use of ATMs and the level of banking inclusion of populations in the Union is consistent with that of [14]. This author finds that, in a sample of OECD countries, the use of ATMs improves the level of financial inclusion of the population. He also corroborates the research findings of [28] who find that financial innovations (internet banking, use of ATMs and mobile phones) improve the financial depth of commercial banks in Kenya.

This research finds that an increase in the number of internet users in the Union significantly improves the level of banking inclusion of populations. This finding is consistent with those of $[15,18]$. These authors concluded in their research that people's use of the internet improved the level of financial inclusion of people in India and Nigeria respectively. This finding of the positive and significant effect of internet use on the banking inclusion of populations suggests that the process of mobile banking currently underway in the Union will improve the level of banking inclusion of populations in the Union.

The results corroborate the research findings which conclude that there are positive and significant effects of the use of ICT by banks and populations on the level of banking inclusion of populations. The hypothesis of the present research that ICTs significantly improve the level of banking inclusion of the populations in the WAEMU is confirmed with respect to the results of the model estimation.

Apart from technological variables, the influence of other variables on the level of banking inclusion of the populations in the WAEMU was analyzed in this research. The results show that the increase in the level of real gross domestic product per capita significantly improves the level of banking inclusion of the populations in the Union. The mechanism being that the higher the income of the populations becomes, the more some of them tend to turn to banks to save the unconsumed fraction of it. It should be mentioned that the level of income of the population plays a major role in the banking inclusion of the population in the Union. Indeed, around 59\% of adults surveyed in 2017 in the Union say they do not have an account with a financial institution in general due to insufficient income [8].

The research results also show that a decrease in banks' operating costs significantly improves the level of banking inclusion of populations. In any production process, the related overall cost is a production constraint and therefore influences the overall production level of a given production unit. At the level of the banking sector, its reduction gives banks the opportunity to improve their accessibility to the population by enlarging the banking network, on the one hand. On the other hand, its reduction may make it possible to improve the availability of banking services to the population by lowering the cost of these services or by diversifying the offers of banking services to the population.

The negative relationship that emerges in this research between the cost of operating banks and their level of inclusion could also serve as an indirect channel for ICTs to have a positive impact on the level of banking inclusion of populations. Indeed, the use of ICTs by banks is likely to reduce their transaction costs [29-31]. However, this indirect relationship between banks' use of ICTs and their level of inclusion is not taken for granted in this research because it has not been the subject of empirical analysis.

Furthermore, it is important to note that the results show that an increase in the lending interest rate of banks in the Union leads to an improvement in the level of banking inclusion of the population. Indeed, an increase in the lending interest rate, as long as it remains below the equilibrium interest rate threshold for the banks' portfolio, will stimulate the supply of bank credit to the population. In a banking system with credit rationing, this additional supply of bank credit to the population will meet a demand for banking services on the part of the population. The end result is that the level of use of banking services by the population will improve.

\section{Conclusion and Implications}

The objective of the research was to analyze the effects of ICTs on the level of banking inclusion of populations in the WAEMU. The contribution of the research was part of the exploration of new avenues through which the level of banking inclusion of populations in the WAEMU could be improved.

The research adopted a linear panel data model for the empirical analysis of the relationship between ICTs and the level of banking inclusion of the populations. The model was estimated over the period 2006-2016. The panel- 
corrected standard error estimator was used for its estimation. The results showed that the spread of the Internet among the population and the evolution of the number of automated teller machines (ATMs) have a positive and significant influence on the level of banking inclusion of the population in the WAEMU. The research hypothesis was confirmed.

These results show that the research objective has been achieved. This research shows that the offer of mobile and automated banking services respectively through mobile banking and ATMs is a good way to improve the level of banking inclusion of the populations in the WAEMU.

To this end, the research suggests to the populations in the Union the adoption and use of ICTs to access mobile and automated banking services because this new mechanism offers them more chance and ease to get banked. It suggests that the political authorities in the various Union Member States should work towards making the Internet more widely available to the public. As the Internet is the main medium for mobile banking, its widespread distribution among the population gives them more motivation to adopt and use mobile banking. It also suggests that banks in the Union should continue to further adapt the offer of banking services through ATMs and mobile banking with a view to improving the level of banking inclusion of the populations in the Union.

\section{References}

[1] Meisel, N., \& Mvogo, J.-P. (2007). Quelles politiques de développement financier en zone franc? Paris: AFD.

[2] BCEAO. (2018). Rapport annuel sur la situation de l'inclusion financière dans l'UEMOA au cours de l'année 2017, 29 p.

[3] Stiglitz, J. E., \& Weiss, A. (1981). Credit Rationing in Markets with Imperfect Information. The American Economic Review, Vol. 71, No. 3, pp. 393-410.

[4] Sawadogo, H. (2014). Les asymétries d'information et rationnement du crédit bancaire dans les pays de l'UEMOA: une validation empirique en données de panel. Ouagadougou, Université Ouaga II, thèse de doctorat ès Sciences économiques, $190 \mathrm{p}$.

[5] North, D. C. (1990). Institutions, institutional change and economic performance. New York: Cambridge university press.

[6] Keho, Y. (2012). Le rôle des facteurs institutionnels dans le développement financier et économique des pays de l'UEMOA. Revue économique et monétaire de la BCEAO, pp. $9-44, \mathrm{~N}^{\circ} 12$.

[7] Freixas, X., \& Rochet, J.-C. (1999). Microeconomics of banking. Cambridge: MIT Pres, fourth printing.

[8] Demirgüç-Kunt, A., Klapper, L., Singer, D., Ansar, S., \& Hess, J. (2018). Global Findex Database 2017: Measuring Financial Inclusion and the Fintech Revolution. World Bank, Washington, DC.

[9] Klein, O. (2015). " Banque et nouvelles technologies: la nouvelle donne ». Revue d'économie financière, $\mathrm{n}^{\circ} 120$, p. 17-
22.

[10] Brack, E. (2016). « La transformation digitale de l'intermédiation bancaire ». Géoéconomie, N81, p. 79-91.

[11] Beck, T., \& De La Torre, A. (2006). The Basic Analytics of Access to Financial Services. Financial Markets, Institutions \& Instruments, $\mathrm{N}^{\circ} 16$, pp. 79-117.

[12] Sarma, M. (2012). Index of Financial Inclusion - A measure of financial sector inclusiveness. Working Paper No. 07, 37 p.

[13] Andrianaivo, M., \& Kpodar, K. (2011). ICT, financial inclusion, and growth: Evidence from Africa countries. IFM Working paper, $\mathrm{WP} / 11 / 73,46 \mathrm{p}$.

[14] Van der Werff, A. D., Hogarth, J. M., \& Peach, N. D. (2013). A cross-country analysis of financial inclusion within the OECD. Consumer Interests Annual, Vol. 59, pp. 1-12.

[15] Kaur, K., \& Singh, J. (2015). The role of ICT infrastructure in financial inclusion: an empirical analysis. ELK Asia Pacific Journal of Finance and Risk Management, Volume 6 Issue 3, pp. 69-79.

[16] Mago, S., \& Chitokwindo, S. (2014). The impact of mobile banking on financial inclusion in Zimbabwe: A case for Masvingo Province. Mediterranean Journal of Social Sciences, Vol 5 No 9, pp. 221-230.

[17] Lohani, V. J. (2015). Technology as a decision maker for banking sector. International Journal of Mathematics and Statistics Invention (IJMSI), Volume 3 Issue 6, pp. 33-35.

[18] Okoroafor, O. K., Adeniji, S. O., \& Awe, E. (2018). Empirical Analysis of the determinants of financial inclusion in Nigeria: 1990-2016. Journal of Finance and Economics, Vol. 6, pp. 1925.

[19] Sarma, M. (2008). Index of Financial Inclusion. Indian Council for Research on International Economic Relations, Working Paper No. 215, 26 p.

[20] Arora, R. U. (2010). Measuring Financial Access. Griffith University, Discussion Paper Economics 7, ISSN1837-7750.

[21] Andrianaivo, M., \& Kpodar, K. (2012). Mobile phones, financial inclusion, and growth. Review of Economics and Institutions, Vol. 3, pp. 1-30.

[22] Martinez, C., \& Krauss, A. (2015). What Drives Financial Inclusion at the Bottom of the Pyramid? Empirical Evidence from Microfinance Panel Data. CMFWorking Paper Series, No. 02-2015.

[23] Sreedevi, V., \& Meena, K. (2011). ICT for financial inclusion. International journal of business management, economics and information technology, Vol. 3, $\mathrm{N}^{\circ} .2$, pp. 331-334.

[24] Sundaram, N., \& Sriram, M. (2016). Branchless Banking Technologies and Financial Inclusion: An Investigation in Vellore District, Tamil Nadu, India. Indian Journal of Science and Technology, Vol 9 (40), 5 p.

[25] Calem, P. S., \& Nakamura, L. I. (1998). Branch banking and the geography of bank pricing. The Review of Economics and Statistics, MIT Press 80 (4): 600-610.

[26] Kumar, N. (2013). Financial inclusion and its determinants: evidence from India. Journal of Financial Economic Policy, Vol. 5 Iss 1, pp. 4-19. 
[27] Beck, N., \& Katz, J. N. (1995). What to do (and not to do) with Time-Series Cross-Section Data. The American Political Science Review, Volume 89, pp. 634-647.

[28] Mwai, A., Memba, F. S., \& Njeru, A. (2018). The relationship between ATM banking and financial deepening of commercial bank in Kenya. International journal of economics, commerce and management, Vol. VI, Issue 12, pp. 496-514.

[29] Daley, N. (2003). Les TIC et la banque de détail. Perspectives et enjeux. Les Cahiers du numérique, Vol. 4, pp. 115-129.
[30] El Fidha, C., \& Charki, M. H. (2008). «Le rôle des technologies de l'information et de la communication dans le développement de la qualité de la «relation client». Application à la relation banque/entreprise». Revue des sciences de gestion, $\mathrm{n}^{\circ} 229$, p. 121-127.

[31] Hamdi, H., \& Sbia, R. (2009). La concurrence dans le marché bancaire à l'ère de l'économie numérique: le cas français. Rivista di Studi Politici Internazionali, Nuova Serie, Serie Serie Vol. 76, N², pp. 206-230. 